\title{
Assessment of Variability, Correlation and Response to Selection in Four Cultivars of Sweet Potato "Ipomia batata, L." under Alexandria Environmental Condition
}

\author{
Gehan A. EL-Sharkawy \\ Vegetable Crops Department, Faculty of Agriculture, Alexandria, University, Alex., Egypt. \\ Gehan.mohamed@alexu.edu.eg
}

\begin{abstract}
The efficiency of two cycles of clonal selection on some economical characters in four different varieties of sweet potato (Abbies, Mabrouka, Beaurogard and local Nigerian variety) were studied. The magnitude of variability, heritability and response to selection, as well as phenotypic correlation coefficients among all possible pairs of the studied characters were measured. This work was carried out at the Experimental Station Farm (at Abies), Faculty of Agriculture, Alex. Univ., Alex. Governorate, Egypt during three summer seasons of 2016 - 2018. The obtained results illustrated generally that the estimated coefficients of variability and ranges of the studied characters of the four cultivars original populations reflected high and enough variability, which suggested high possibilities of conducting successful and efficient selection. This lead to produce improved cultivar with better performance than its original population. Also, the results demonstrated, in general, that two cycles of clonal selection exhibited high efficiency for improving all studied characters with different rates, compared with the original population. The estimated values of heritability $\left(\mathrm{h}^{2}\right.$ bs $)$ for the various studied characters were found to be high for dry matter and very low for root diameter. The highest estimates of genetic advance as percentage of mean were obtained for root number ${ }^{-1}$ plant $99.7 \%$, root weight plant ${ }^{-1} 89.0$ $\%$, root length $77 \%$ and vine length $69.2 \%$. The results also, revealed that phenotypic clonal selection was ended up with populations that have improved root number plant ${ }^{-1}$ for Abbies, Mabrouka and beaurogard by $77.87 \%, 101.9 \%$ and $51.71 \%$, respectively, in respect to the original population. The increment over original population for fruit number plant ${ }^{-}$ ${ }^{1}$ in Nigerian variety was observed in $\mathrm{C}_{1}$ population which reached $53 \%$. Meanwhile, the results also demonstrated that Abbies produced the maximum number of tubers plant ${ }^{-1}$ (5.87 tubers) and the highest root weight plant ${ }^{-1}$ was observed in Beaurogard (1.67 kg/ plant). Moreover, Abbies variety had the highest values for dry matter, TSS and carotene content and it was statistically different from the remaining three sweet potato varieties. Furthermore, correlation estimates revealed significant associations among the various pairs of the studied characters. These findings appeared to be desirable for achieving the objectives of the selection in the present study. Accordingly, improving roots yield and its components of sweet potato can be achieved through purification of the most important and commercial cultivars to produce improved clones through clonal selection program.
\end{abstract}

Keywords: Sweet potato, clonal selection, heritability, correlation, genetic variability.

\section{INTRODUCTION}

Sweet potato [Ipomoea batatas (L.) Lam] is a member of the Convolvulaceae family and considered one of the most important popular starchy tuber and food crop in Egypt as well as many other tropic and sub-tropic countries (Austin, 1988). This family includes 55 genera and more than 1000 species. However, only Ipomoea batatas it has economic importance as a source of food (Watson and Dallwitz, 2000).

In developing countries, sweet potato ranks, fifth economically after rice, wheat, maize, and cassava; sixth in dry matter production; seventh in digestible energy production; ninth in protein production (Stathers et al., 2005).

World production of sweet potato is about 131 million tonnes $\mathrm{yr}^{-1}$, on approximately 9 million ha with estimated mean yields of 13.7 tonnes ha ${ }^{-1}$ (FAO, 2017). China is the world's leading producer of sweet potato, accounting for about $80 \%$ of the total production worldwide. Egypt produces 330.382 ton/ ha. The total cultivated area was 13.097 ha (FAO, 2017).
Sweet potato is a very promising crop as a staple food for farmers since it is a very good source of starch and protein. Egypt is considered a very good producer of sweet potato and one of the high ranked countries in sweet potato exportation, specially to Europe. Such factor brings need to improve productivity and quality of the crop. Abbies region in Alexandria is a well-known area for the production of the famous cultivar Abbies. This cultivar is well adapted to the local environment of this region. Nowadays, more cultivars needed to be evaluated to fulfill the requirement of exportation. Moreover, due to the deterioration in productivity of the local varieties of sweet potato, breeder devoted their efforts to improve the productivity through selection in the base population through extent breeding program (Soliman and Ragheb, 2016).

The relatively, low yield productivity of sweet potato and great variability which noticed among individual plants of commercially grown population; it is vital to start a breeding program. Since it is well known that sweet potato is one of the most important crop belong to asexualy group 
clonal selection method considered more suitable for improvement of sweet potato. Selection of individuals within the population, have to be considered by the breeder and the value of a genotype is determined by a good performance overall traits. Yield is the most relevant trait together with several nutritional quality traits should be considered. Many investigators studied the effects of clonal selection method to improve asexual propagated vegetable crops, such as garlic (Lammerink and Wallace, 1987; Sakr, 1996), artichoke (Habib, 2001), potato (Souza, 2005) and sweet potato (Gunjan, 2012). Whereas, their results indicated that using clonal selection program was an effective method in improving the studied characters of these crops. The magnitude of variability among sweet potato genotypes; which estimated by Anshebo et al. (2004); Engida et al. (2006 and 2007); Gunjan (2008 and 2012) recorded considerable variability among the genotypes for the characters under consideration.

It is known that the effectiveness of plant breeding programs, particularly, in selection depends on the relative importance of genetic and non-genetic factors in the expression of phenotypic differences among genotypes in a population, referred to heritability. Heritability is a measure of genetic relationship between parent and progeny and has been widely used in determining the degree to which a character might be transmitted from parents to offspring. Heritability estimates for some important characters of sweet potato carried out by several researchers (Evoor et al., 2008; Gunjan, 2012; Wera et al., 2014; Sandhu et al., 2015).

Selection for storage root yield, which is a polygenic trait, often leads to changes in other characters. Therefore, knowledge of the relationship that exists between storage root yield and other characters and interrelationships among various characters is necessary in order to design appropriate selection criteria in sweet potato breeding programs. In this respect, phenotypic correlation coefficients between various pairs of sweet potato characters were estimated by many investigators (Teshome et al., 2004; Devi et al., 2008; Gedamu et al., 2010; Afuape et al., 2011; Gunjan, 2012).

Accordingly, the present study was established to determine: 1) The efficiency of two cycles of clonal selection for yield in three local varieties beside one Nigerian local variety. 2) Testing the interrelationships among the various studied agronomic traits, using the estimation of phenotypic correlation coefficients. 3) Detecting genetic diversity and heritability estimates for various characters.

\section{MATERIALS AND METHODS}

\section{Experimental site}

During the summer seasons of 2016, 2017 and 2018, field trials were carried out at the Experimental Station Farm, Abies region, Faculty of Agriculture, Alexandria University, Alexandria Governorate, Egypt. This sites lies between latitude $31^{\mathrm{O}} 2 \mathrm{~N}$, and longitude $29^{\mathrm{O}} 6 \mathrm{E}$ with an latitude of about $2.5 \mathrm{~m}$ below sea level.

\section{Original genetic material (First season)}

Four varieties of sweet potato, two local Egyptian varieties called Abbies , and Mabrouka $\left(\mathrm{V}_{1}\right.$ and $\left.\mathrm{V}_{2}\right)$, and well established American variety Beaurogard $\left(\mathrm{V}_{3}\right)$ and a local Nigerian variety $\left(\mathrm{V}_{4}\right)$ grown for first time in Egypt were used to evaluate its performance. The characteristics of the used varieties are shown in (Table 1). The local varieties were obtained from a Commercial nursery in Alexandria .The beaurogard tubers were obtained from Agro Food Company. However, the Nigerian variety was obtained through personal communication with one Nigerian colleague. The clonal selection breeding program started with commercial population consisting of about 1000 stem cuttings from each cultivar, both top and middle portions of vine cuttings of mature plants. A $(3-4)$ nodes and about $(20-30 \mathrm{~cm})$ long were clipped off and planted on one side rows on April $20^{\text {th }} 2016$. The experimental area included 190 rows, $4.0 \mathrm{~m}$ long and $0.7 \mathrm{~m}$ wide. The spacing between plants was $0.25 \mathrm{~m}$. All agricultural practices such as fertilization, irrigation and pests control were performed as recommended for commercial sweet potato production.

The recorded data for the original population $\left(\mathrm{C}_{0}\right)$ of each variety were measured on the basis of 30 individual plants of each variety at two periods. The first period was about 110 days from transplanting when the plants were totally grown, where three vegetative growth characters; i.e., vine length $(\mathrm{cm})$, foliage weight $(\mathrm{g})$ and branches number plant ${ }^{-1}$ were determined.

Table 1: Characteristics of the studied varieties.

\begin{tabular}{lcccccc}
\hline Cultivar & & Leaf shape & Skin color & Flesh color & Maturity & Productivity (ton/ha) \\
\hline Abbies & $\left(\mathrm{V}_{1}\right)$ & Lobed & Orange & Red & $125-135$ & 10 \\
\hline Mabrouka & $\left(\mathrm{V}_{2}\right)$ & Heart shape & Cream & Red & 165 & 12 \\
\hline Beaurogard & $\left(\mathrm{V}_{3}\right)$ & Heart shape & Orange & Red-orange & 130 & 13 \\
\hline Nigerian local & $\left(\mathrm{V}_{4}\right)$ & Heart shape & Cream & Cream & 150 & 5 \\
\hline
\end{tabular}


And, the second period at the harvesting stage it was after about 135 days from transplanting, storage roots were dug up of each hill, then the following characters were recorded; root length $(\mathrm{cm})$, root diameter $(\mathrm{cm})$, root weight $(\mathrm{g})$, roots number plant ${ }^{-1}$, total roots yield plant ${ }^{-1}$, and roots yield plant ${ }^{-1}$, the statistical parameters; mean (X), rang, and coefficient of variation (C.V. \%) were estimated for each character.

\section{Selection the first clone's generation}

The best 50 plants from the original population of each variety, at the beginning of roots formation, were primarily selected on the basis of the vegetative growth characters, as reported earlier. At harvesting stage, a second selection according to the above-reported traits of the roots yield and its components, were conducted to come out 18 plants. The stem cuttings of each selected plants from each cultivar were cut separately transplanted in the nursery on September $10^{\text {th }}$ of 2016 , for the next evaluation season for derived clones $\left(C_{1}\right)$. In 2017 the population of $\left(\mathrm{C}_{1}\right)$ from each variety were sown and by the end of the season and more severe selection were done based on the same characteristics of high productivity and root shape to end up finally with nine best plants (clones ) from each cultivar $\left(\mathrm{C}_{2}\right)$.

In 2018 Stem cuttings of each selected clone from each variety $\left(\mathrm{C}_{2}\right)$ and representative samples of the original population $\left(\mathrm{C}_{0}\right)$ and $\left(\mathrm{C}_{1}\right)$ population of each variety were prepared and transplanted in summer season on April 20, 2018. A randomized complete blocks design (RCBD) with three replicates were used. Each plot consisted of three rows, $4 \mathrm{~m}$ long and $0.70 \mathrm{~m}$ wide. The planting was done on the rows at $0.25 \mathrm{~m}$ spacing and all recommended cultural practices for commercial sweet potato production were followed.

Data were measured for 5 plants from each of the selected nine clones of each variety $\left(C_{2}\right.$ population). Length $(\mathrm{cm})$, foliage weight $(\mathrm{g})$, root length $(\mathrm{cm})$, root diameter $(\mathrm{cm})$, root weight $(\mathrm{g})$, roots number plant ${ }^{-1}$, total roots yield plant ${ }^{-1}$, roots yield plant ${ }^{-1}$, average root weight $(\mathrm{g}), \mathrm{L} / \mathrm{D}$ ratio ( length / diameter), TSS ( total soluble solids), root dry matter (\%), and the carotene content $(\mathrm{mg} / 100 \mathrm{~g}$ fresh weight), sugar content $\%$ and starch content $\%$ was assayed according to Davies procedure (1976).

\section{Statistical analysis}

The mean performance of individual genotype was pooled and employed for statistical analysis. Analysis of variance was carried out according to by Gomez and Gomez (1984) using (Co-stat software 2004). Phenotypic coefficient of variability (PCV) and genotypic coefficient of variability (GCV) and heritability in broad sense $\left(\mathrm{h}^{2}\right.$ bs $)$ were calculated by the formula given by Burton and De Vane (1953). Genetic advance that is the expected genetic gain was calculated by using the procedure given by
Johnson et al. (1955). Correlation coefficient was worked out as method suggested by Searle (1961). The estimated values were compared with table values of correlation coefficient to test the significance of correlation coefficient.

\section{RESULTS AND DISCUSSION}

The data in Table (2) showed significant differences amongst varieties for most of the studied characters. This shows phenotypic and genotypic diversity among them. Abbies produced the maximum number of tubers (5.87 tubers) followed by Beaurogard without significant difference. The highest root weight plant $^{-1}$ was observed in Beaurogard (1.67 kg / plant) followed by Mabrouka without significant difference. The highest average tuber weight observed in the Nigerian variety $720 \mathrm{~g}$ followed by Mabrouka and Beauregard. Abbies and Mabrouka showed the highest significant foliage weight. No significant differences among varieties were observed in root diameter and sugar content. Abbies variety had the highest values for dry matter, TSS and carotene content and it was statistically different from the remaining three sweet potato varieties. The Nigerian variety had the lowest number of tubers and the lowest weight of tuberous root plant $^{-1}$ and starch content. This could be explained as the variety was grown for the first time in Egypt and is not adapted to Egypt conditions. More research should be done to improve the variety and evaluate it under extra environments to ensure its performance. These results are in agreement with Lewthwaite and Triggs (2000) whom reported that sweet potato cultivars varied significantly in total yields. They contribute the increasing in total yield due to the increase in root weight and depend on leaf photosynthesis. Also, Sasaki et al. (2005) suggested that the canopy type might affect the NAR (Net Assimilation Rate) of each cultivar. The transport of assimilates from the leaves to the root stalk is a process influenced by storage root growth, as storage root cells must be formed and expand before they can store assimilates. As well as, the final yield depends on the rate of increase and the duration of growth. Ayoub (2005) and Shehata et al. (2006) found that cv. Mabrouka gave higher dry matter than the other tested cultivars. Ali et al. (2009) showed that maximum number of tuber roots plant ${ }^{-1}(5.13$ tubers), average diameter of tuber roots $(3.87 \mathrm{~cm})$. Also, Esan and Omilani (2018) in there study on four Nigerian varieties mentioned that Iwo 1 was the highest yielding variety among the remaining ones. However, Rahman et al. (2013) indicated that CIP440267 was suitable for cultivation in Bangladesh among other varieties as an orange fleshed sweet potato variety. 
Values for the statistical parameters; means (X), ranges (R) and coefficients of variation (C.V. \%) for all the studied characters of the original population of the four used varieties of sweet potato are given in Table (3). The recorded result indicated that the original population expressed high variability for most studied characters as appeared from the estimated values of coefficients of variation which ranged from 17.91 to $20.93 \mathrm{~cm}$ in plant length, 22.75 to $31.55 \mathrm{~g}$ in foliage weight, 24.77 to 44.35 branches in number of branches, 15.17 to $21.55 \mathrm{~cm}$ for root length and from 15.08 to $25.19 \mathrm{~cm}$ in fruit diameter. However, the yield characters showed the highest values for coefficients of variation which ranged from 39.3 in Beaurogard to 55.33 in the Nigerian variety for root yield plant $^{-1}$ and from 39.62 in Abies cultivar to 60.26 in the Nigerian variety. Also, all studied characters had wide range between the lowest and highest value for each character. Such results may be explained as the studied varieties have been commercially grown without any purification for a long time. Therefore, this supported the high possibilities of conducting successful and efficient selection to introduce clones, with better performances than their original population. These results were in confirmatory with the findings of other workers, Engida et al. (2007) and Gunjan (2008) for number of roots plant ${ }^{-1}$; Teshome et al. (2004); Engide et al. (2007); Evoor et al. (2008); Gunjan (2008) for root length. and Teshome et al. (2004); Engida et al. (2007); Gunjan (2008) for roots yield plant ${ }^{-1}$.

The analysis of variance illustrated in Fig. (1) revealed the existence of significant variation among the three populations [the original population $\left(\mathrm{C}_{0}\right)$ and the two selected derived populations $\left(\mathrm{C}_{1}\right.$ and $\left.\mathrm{C}_{2}\right)$ ]. The data of the selected population $\left(\mathrm{C}_{2}\right)$ were the average of the selected clones (clone 1 to clone 9). The obtained results indicated clearly that $\left(\mathrm{C}_{2}\right)$ population showed different degree of superiority over the original population. Mean comparisons indicated that $\mathrm{C}_{2}$ had the highest values for plant height in Nigerian variety (Fig. 1). For foliage weight, $\mathrm{C}_{2}$ had the highest values for all cultivars. However, for number of roots plant ${ }^{-1}, \mathrm{C}_{2}$ achieved the highest values in Abbies, Mabrouka and Beuarogard (Fig. 1). For plant yield the highest increment were obtained in Mabrouka and Beaurogard varieties.

The $\mathrm{C}_{2}$ population in Nigerian variety showed the highest values for fruit length and Mabrouka for fruit diameter. Thus the clonal selection improved the performance of the sweet potato used varieties in most of the studied characters at different magnitude. As shown by the final concurrent evaluation for the three population $\left(\mathrm{C}_{0}, \mathrm{C}_{1}\right.$ and $\left.\mathrm{C}_{2}\right)$, the phenotypic clonal selection was ended up with populations that have improved root number plant $^{-1}$ in Abbies, Mabrouka and Beaurogard by $77.87 \%$,
$101.90 \%$ and $51.71 \%$, respectively relative to the original population. The increment over original population for fruit number plant $^{-1}$ in Nigerian variety was observed in $\mathrm{C}_{1}$ population which reached $53 \%$. Meanwhile, for root yield plant $^{-1}, \mathrm{C}_{2}$, populations showed the highest improvement reached to $121 \%$ and $80 \%$ in Mabrouka and Beaurogard, respectively. However, $\mathrm{C}_{1}$ showed the highest significant increment in Abbies and Nigerian variety with values reached $21 \%$ and $48 \%$ respectively. This results regarding new sweet potato clones were realized by several workers, Omran (2002); Wanas (2002); Aushebo et al. (2004) and Soliman and Ragheb (2016).

The extents of variability in sweet potato were measured over all the studied genotypes in the $C_{2}$ populations Table (4). Environmental $\sigma^{2}$, phenotypic $\sigma^{2}$ ph and genotypic $\sigma^{2}$ variance were estimated. The parameters phenotypic coefficient of variation PCV and genotypic coefficient of variation GCV, Heritability in broad sense $\mathrm{h}^{2}$ bs, genetic advance GA and genetic gain $\mathrm{G} \%$ were calculated as well. The results revealed considerable phenotypic and genotypic variation among genotypes for all the studied characters. In most of the characters a large portion of the phenotypic variance was accounted by the genetic component. High magnitude of PCV and GCV in foliage weight, root number plant ${ }^{-1}$, root weight plant $^{-1}$ root length, $\mathrm{L} / \mathrm{D}$ ratio, TSS, and dry matter. The estimated different two values differ only slightly indicating that influence of environment of these characters are negligible and the role of genotypic performance in the full expression of the genotype. Vine length, root number plant ${ }^{-1}$ and root weight plant $^{-1}$ had moderate GCV and PCV, and hence these characters provide average chance for selection. On the contrary, L/D ratio TSS and total sugar $\%$ had the least PCV and GCV supposing less chance for selection. These results are in agreement with the findings of Sharma (2004), Engida et al. (2006) and Sharavati et al. (2018) in sweet potato.

The estimates of heritability in broad sense for roots number plant $^{-1}$, root length, and dry matter characters showed, relatively, high value of $80.42 \%, 85.33 \%$ and $94.55 \%$, respectively. This demonstrated that genetic variance seemed to contribute with relatively high portion of the total variance. Moderate heritabilities were observed for foliage weight root weight, L/D ratio, TSS, starch content and carotene content $(68.28 \%, 66.8 \%$, $71.52 \%, \quad 74.58 \%, \quad 59.74 \%$ and $52.51 \%$, respectively). The high and moderate heritabilities indicated that those characters were less influenced by environmental fluctuations. Hence, selection for these traits might lead to accumulation of more desirable genotypes and satisfactory progress could be achieved by individual selection on these characters. 

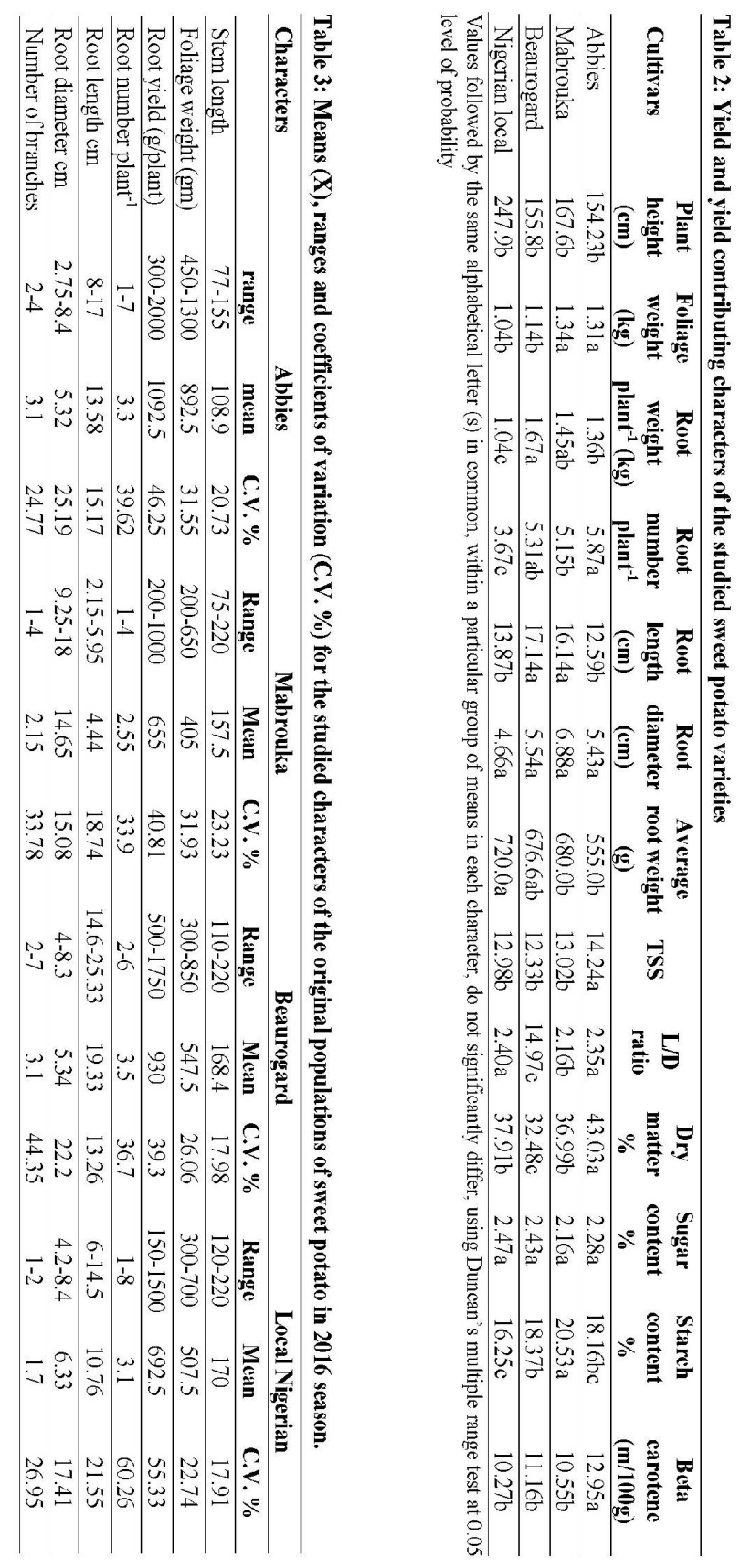

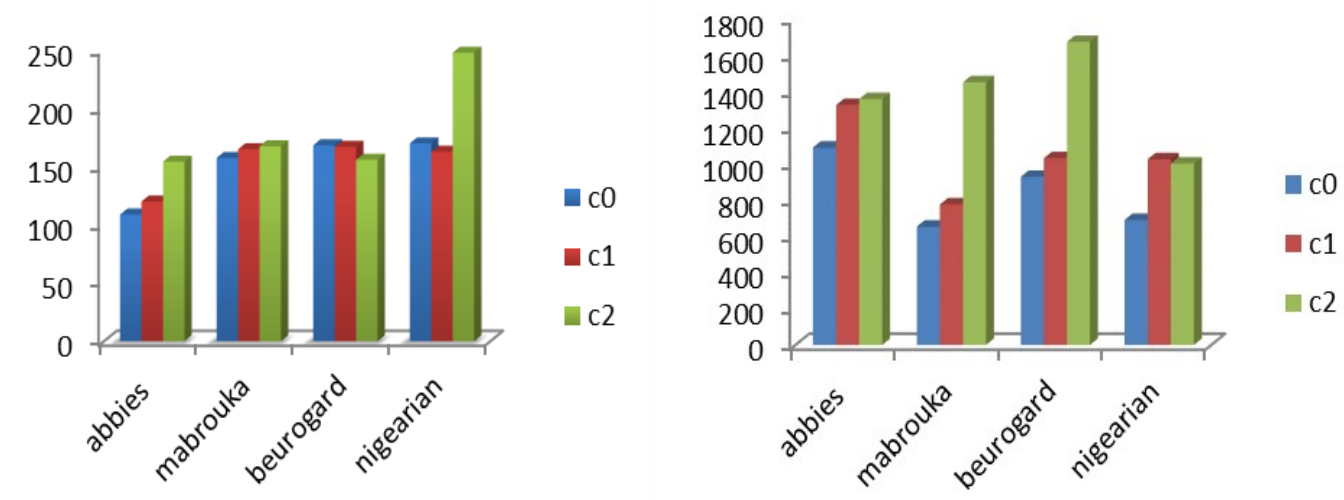

a
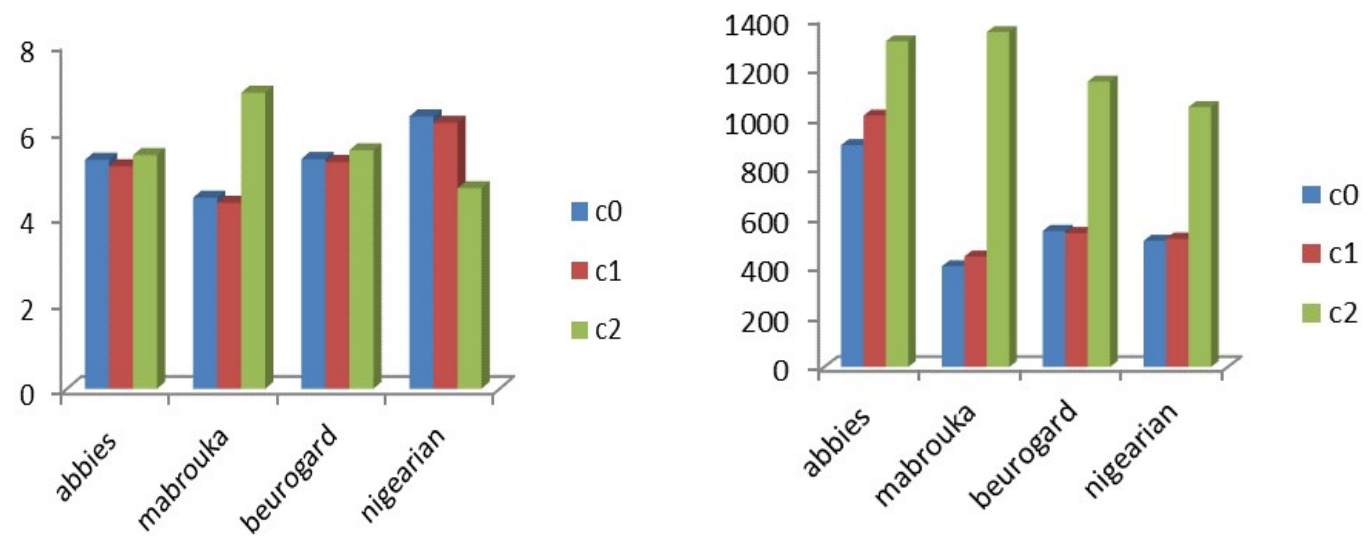

C
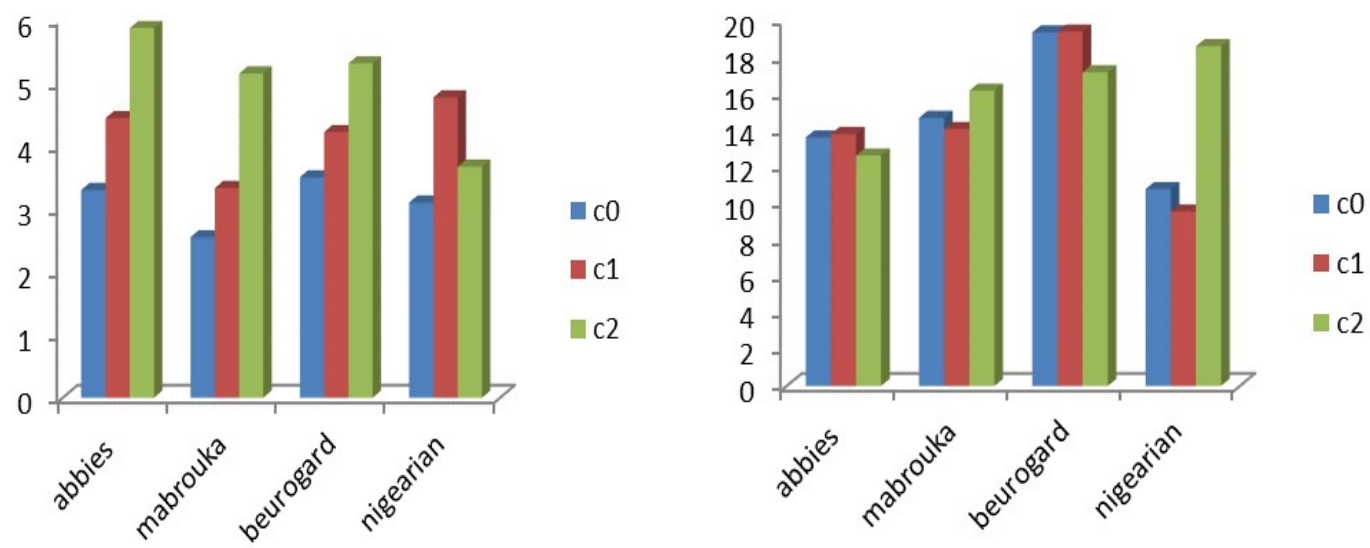

e

f

Fig. 1: a) Vine length (cm), b) Foliage weight (g), c) Number of roots plant ${ }^{-1}$, d) Weight of roots plant ${ }^{-1}$ $(\mathrm{g})$, e) Root diameter $(\mathrm{cm})$, and $\mathrm{f})$ Root length $(\mathrm{cm})$, for base population $\left(\mathrm{C}_{0}\right),\left(\mathrm{C}_{1}\right)$ and second $\left(\mathrm{C}_{2}\right)$ cycles populations of sweet potato varieties Abbies, Mabrouka, Beaurogard and Nigerian local variety grown in Alexandria, 2016 - 2018. 


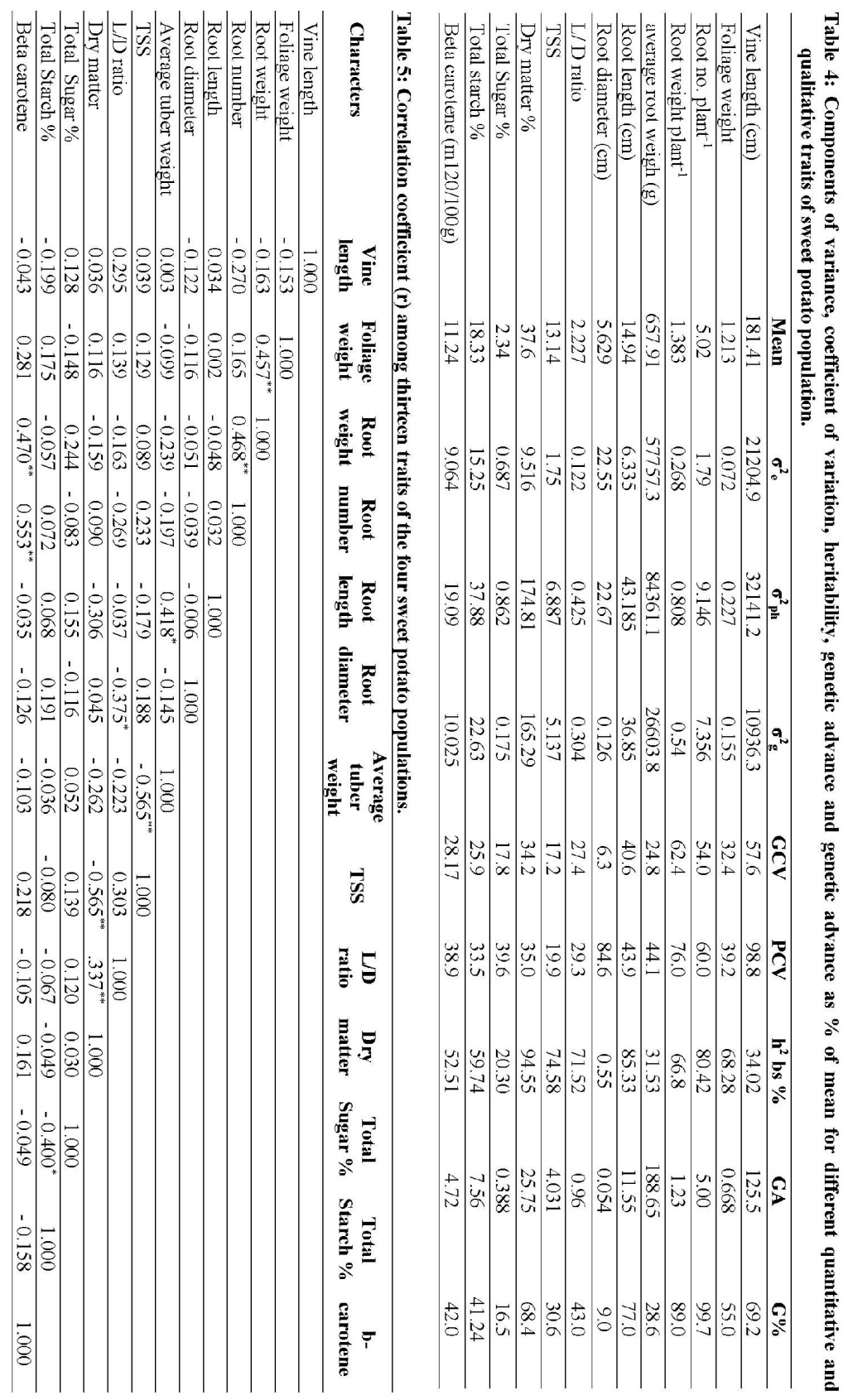


The present findings were in agreement with findings reported by the various workers viz., Teshome et al., (2004); Engida et al., (2006) and Shashikanth et al., (2008) in sweet potato.

Genetic advance is important to find out the genetic gains which likely to be achieved in the next generation. These are classified as high, medium and low. The success of genetic advance under selection mainly depends upon genetic variability, heritability and selection intensity. In the present study highest estimates of genetic advance as percentage of mean were obtained for characters viz., root number plant ${ }^{-1} 99.7 \%$ root weight plant ${ }^{-1}$ $89.0 \%$ root length $77 \%$ and vine length $69.2 \%$. The moderate estimate of genetic advance as percentage of mean were obtained for characters viz., foliage weight $55 \%$, L/D ratio $43 \%$ starch content $41 \%$ and carotene content $41.24 \%$ (Table 3 ). In the present study, high heritability coupled with high genetic advance as per cent over mean was recorded for the characters viz., root number plant $^{-1}$ root weight plant ${ }^{-1}$ root length and dry matter. Whereas, moderate heritability coupled with moderate genetic advance as per cent over mean was recorded for L/D ratio and foliage weight. High heritability coupled with moderate genetic advance as per cent over mean was recorded for starch content and carotene content. The above findings indicated that the characters with the high and moderate heritability and genetic advance can be considered for direct selection for improvement. These results are in agreement with the results of Engida et al., (2006); Shashikanth et al., (2008); Madawal et al., (2015); Demelie and Aragao (2016) and Badu et al., (2017) in sweet potato.

With regard to the estimated values of phenotypic correlation coefficients among all possible pairs of the studied characters, the obtained results are presented in Table (5). Generally, 10 out of the possible 78 relationships appeared to be desirable for the improvement of sweet potato using clonal selection method, and highly correlated, since their estimated correlation coefficients were found to be either significant or highly significant. On the other hand, the other phenotypic correlation coefficients (68 relationships) were found too small to be significant. Desirable association were detected between total roots yield plant ${ }^{-1}$ with each of foliage weight, root number plant ${ }^{-1}$ and carotene content (with a positive trend). In the same line, desirable correlation coefficients were observed between root number plant ${ }^{-1}$ and beta carotene content with positive associations. Gedamu et al. (2010) found that total yield reflected positive effect with each of marketable and root weight. The existence of significant association between total roots yield and average roots weight was confirmed by Islam et al. (2002) and Engida et al. (2006). The results indicated also, that the character of root diameter reflected negative and significant correlation with L/D ratio. Highly significant positive correlations were observed between average root weight and root length and between $\mathrm{L} / \mathrm{D}$ ratio and dry matter. On the other hand, negative correlations were showed between dry matter and TSS and between sugar content starch content (with highly significant level). These results indicated that increasing any of these characters would be associated with a reducing effect on the other, suggesting that attention should be given in breeding programs for these characters. Various workers studied the relationships between different traits in sweet potato such as Islam et al. (2002); Engida et al. (2006). Islam et al. (2002) showed that the characters vine length, number of roots and root diameter recorded positive and significant correlation with roots yield character. While, Alcoy (2007) reported a significant association between total roots yield and marketable roots yield.

\section{CONCLUSION}

All selected clones after two cycle of clonal selection breeding program reflected improvement and superiority over the original population, for all studied characters with different degrees. The results of variance components and heritability estimates indicated that most of the variability were due to genetic variation. Accordingly, improving roots yield and its components of sweet potato might be achieved through purification of sweet potato cultivars and introducing improved clones through clonal selection program.

\section{REFERENCES}

Afaupe, S. O.; P. I. Okocha and D. Nook. 2011. Multivariate assessment of the agro morphological variability and yield components among sweet potato landraces. Afri. J. Pl. Sci., 5(2): 123-133.

Alcoy, A. B. 2007. Plant to plant yield variability of sweet potato [Ipomoea batatas (L.) Lam] as affected by plant material and time of harvest. MMSU Sci. Techn. J., 1(1): 43 - 50.

Ali, M. R., D. J. Costa, M. J. Abedin, M. A. Sayed and N. C. Basak, 2009. Effect of fertilizer and variety on the yield of sweet potato. Bangladesh J. Agri. Res., 34(3): 473-480.

Allard, R. W. 1960. Principles of plant breeding. John Willey and Sons Inc., New York, USA., $485 \mathrm{p}$.

Anshebo, T.; D. Veeraragavathatham and M. Kannan. 2004. Genetic variability and correlation studies in sweet potato (Ipomoea batatas L. Lam). Madras Agric. J., 91(7 12): $420-424$. 
Austin, D. 1988. The taxonomy, evolution and genetic diversity of sweet potatoes and related wild species. In: International Potato Center (CIP). Explor. Maint. \&Utiliz. Sweet potato Gen. resou. pp. 27-59.

Ayoub, I. I., 2005. Effect of fertigation and plant population on growth, yield and storability of sweet potato grown under sandy soil conditions. Ph.D. Thesis, Fac. Agric., Zagazig Univ., Egypt.

Badu, M., P. Asho, T. S. K. Patro, and K. Sasikala. 2017. Studies on genetic variability, heritability and genetic advance for growth, yield and quality parameters among orange flesh sweet potato [Ipomoea batatas (L.) Lam.] Genotypes. Inte. J. of Current Microb. and Applied Sci., 6(9): 1894-1903.

Burton, G. W. and Devane, E. M. 1953. Estimating heritability from replicated clonal material. Agron. J., 45: 478-481.

Co-Stat Software. 2004. User's manual version. Cohort Tusson, Arizona, USA.

Davies, B. H. 1976. Analysis of carotenoid pigment. In: T.W. Goodwin (ed.), Chemistry and Biochemistry of Plant Pigment. Academic Press, London and New York.

Demelie, M. and A. Aragao, 2016. Genetic variability of sweet potato on yield and yield related traits at Werer Agricultural Research Center, Ethiopia. Elect J. of Plant Breed., 7(2): 88-96.

Devi, A. K.; G. Gin and N. B. Singh. 2008. Genetic variability and correlation studies in sweet potato. Orissa J. Hort., 36 (2): 73 - 76.

Engida, T.; S. E. Devakara and D. Nigussie. 2006. Correlation and path analysis in sweet potato and their implications for clonal selection. $J$. Agro., 51(3): 391- 395.

Engida, T.; E. V. Devakara and D. Nigussie. 2007. Genetic variability for yield and other agronomic traits in sweet potato. J. Agro., 6(1): 94 - 99.

Esan, V. I. and O. O. Omilani, 2018. Assessment of four sweet potato varieties for adaptability and productivity in Iwo, Osun state . Assian J. Of Agric. And Horti. Res., 1(1):1-8.

Evoor, S.; M. P. Patil; M. B. Madalageri and R. Mulge. 2008. Genetic variability, heritability and genetic advance in sweet potato (Ipomea batatas L.). Environ. Ecol., 26 (1A): 322 325.

FAOSTAT, (2016). Food and agricultural organization of the united nations; online:

http://www.fao.org/faostat/en/\#data/QC/visua $\underline{\text { lize }}$ (Accessed $25^{\text {th }}$ December 2018).
Gedamu, Y.; G. Belay and N. Dechassa. 2010. Genotypic and phenotypic correlations of root yield and other traits of orange-flesh sweet potato (Ipomoea batatas (L.) Lam. J. Drylands., 3(2): 208- 213.

Gomez, A. K. and A. A. Gomez (1984). Statistical procedures for agricultural research. $2^{\text {nd }}$ ed. John Wiley \&Sons Pub., pp.139-153

Gunjan J. 2008. Estimations of genetic variability in sweet potato. The Ecoscan., 41: 180 -185.

Gunjan J. 2012. Increasing productivity of sweet potato, Ipomoea batatas (L) Lam through clonal selection of ideal genotypes from open pollinated seedling population. Inter. J. Farm Sci., 2(2): 17 - 27.

Habib, R. M. 2001. Efficiency of clonal selection on improving characteristics of artichoke (Cynara scolymus L.). M.Sc. Thesis, Fac. of Agric. Alexandria Univ., Egypt.

Islam M. J.; M. Z. Haque; U. K. Majunder; M. M. Haque and M. F. Hossain. 2002. Growth and yield potential on nine genotypes of sweet potato. Pakistan J. Biol. Sci., 5(5): 537 - 538.

Johnson, H. W., H. Robinson and R. Comstock. 1955. Estimates of genetic and environmental variability in soybeans. Agronomy J., 47 (7): 314-318.

Lammerink, J. and A. R. Wallace. 1987. Effect of clonal selection and planted clove weight on yield of garlic . Proceed. Agro. Soc. New Zealand, 17: 7 -10.

Lewthwaite, S. L. and C. M. Triggs. 2000. Preliminary study on sweet potato growth: I. Dry matter partitioning. Agron. J. New Zealand, 30: 143-149.

Madawal, S. L., Alloli, T. B. S. Madarkhandi, and A. Narasannavar. 2015. Genetic variability study in sweet potato (Ipomoea batatasL.) genotypes. Inte. J. of Tropical Agric., 33(2): 274-282.

Mather, K. and J. L. Jinks. 1971. Biometrical genetics $\left(2^{\text {nd }}\right.$ Ed). Chapman and Hall, LTD. London. 382 p.

Omran, A. F.; R. M. Khalil, N. M. Malash; M. M. El-Sayed; N. M. Wanas and A. M. Salim. 2002. Behavior of some breeds sweet potato lines and their $\mathrm{F}_{1}$ crosses. Minufiya J. Agric. Res., 27(3): 621- 635.

Rahman, M. H., M. M. Alampatwary, H. Baruy, M. Hossain, and S. Nahar, 2013. Evaluation of orange fleshed sweet potato genotypes for higher yield and quality. The Agriculturists, 11(2): 21-27.

Sakr, A. M. 1996. Efficiency of clonal selection in Egyptian and Chinese garlic cultivars. M.Sc. Thesis, Fac. of Agric. Alexandria Univ., Egypt. 
Sandhu, S. S.; P. S. Brar and R. K. Dhall. 2015. Variability of agronomic and quality characteristics of garlic (Allium sativum L.) ecotypes. J. Pl. Breed. \& Genet., 47(2): 133 142.

Sasaki, O., H. Moriyama, K. Yoshida and J. Tedaka, 2005. The morphology of the sweet potato canopy and its varietal differences. Bulletin of the Faculty of Agriculture, Kagoshima University, 55: 1-6.

Searle, S.R. (1961) Phenotypic, genotypic and environmental correlations. Biometrics, 17, 474- 480 .

Sharma, G. P. 2004. Selection of ideal genotypes from open pollinated seedling population of sweet potato [Ipomoea batatas (L.) Lam.]. M.Sc. (Ag.) thesis, IGAU, Raipur.

Sharavati, M. B., V. Srinivasa, R. B. Anusha, and A. S. Shubha, 2018. Genetic variability studies in sweet potato genotypes under hill zone of Karnataka , India . Inter. J. Current. Micro. Appli. Sci., 7(9): 850-858.

Shashikanth, E., P., M. B., Madalageri, R. Mulge, and V. D. Gasti, 2008. Correlation and path analysis studies in sweet potato (Ipomoea batatas(L.) Lam.). Envir. and Eco., 26(1A): 422-426.

Shehata, S. A., A. Abou El-Yazied and M. M. ElMogy. 2006. Effect of fertilization and irrigation on yield and quality of sweet potato. Annals of Agric. Sci. Moshtohor, 44(4):1707-1724.
Solieman, T. H. I. and E. I. M. Ragheb. 2016. Efficiency of clonal selection on improving some economical characters of sweet potato. Alex. J. Agric. Sci., 61(5): 435-442.

Souza, V. Q. 2005. Potential of selection among and within potato clonal families. Crop Breed. \& Appl. Biotech., 5(2): 199 - 206.

Stathers, T., S. Namanda Mwanga, G. ROM, Khisa and R. Kapinga 2017. Manual for sweet potato integrated production and pest management farmer field schools in subSaharan Africa. International Potato Center, Kampala, Uganda, 2005; 1-168. Food and Agriculture Organization Statistics. FAO Statistics. http://faostat.fao.org/site/567/default.asp

Teshome, A.; D. Veeraragavathatham and $M$. Kanan. 2004. Genetic variability and correlation studies in sweet potato. Madras Agric. J., 91(7-12): 420 - 424.

Wanas, N. M. 2002. Evaluation of some new potato varieties under Egyption condition. Minufiya J. Agric. Res., 4(2): 1009 -1016.

Watson, I. and M. J. Dallwitz. 2000. The family of flowering plants. Descriptors, identification and information reterval. wttp: biodiversity (verified 14 december, 2000)

Wera, B.; A. Yalu; A. Ramakrishna and M. Deros. 2014. Genotypic variability estimates of agronomic traits for selection in sweet potato (Ipomoea batatas) polycross population. J. Pl. Breed. \& Genet., 2(3): 131 -136. 


\title{
الملخص العربى
}

\section{تقدير الاختلافات والارتباط والإستجابة للإنتخاب في أربعة أصناف من البطاطا تحت ظروف منطقة الأسكندرية}

\author{
جيهان عبد العزيز الثرقاوي \\ قسم الخضر - كلية الزر اعة - جامعة الاسكندرية.
}

الهدف من هذه الدراسة هو دراسة كفاءة الاتتخاب لدورنين منتاليتين من دورات إنتخاب السلالة الخضرية

لبعض الصفات الاقتصادية في أربعة أصناف من البطاطا (أبيس ومبروكة وبيروجارد وصنف محلي نيجيري).

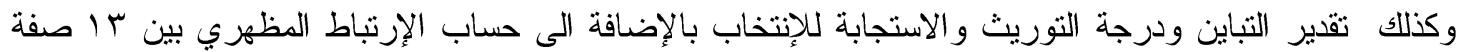
تحت الدراسة. ولذلك أجريت هذه الدراسة في محطة البحوث الزراعية التابعة لكلية الزراعة جامعة الإسكندرية

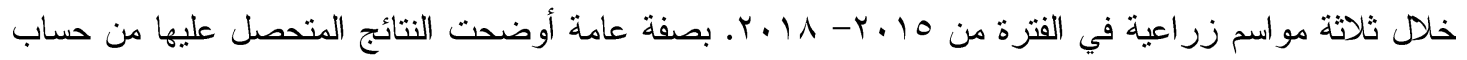
درجة الاختلاف والمدى بين الصفات المختلفة في كل الاصناف الأربعة المدروسة أن الإختلافات الوراثية كانت مرتفعة وكافية للبدء ببر امج و الذي يقود لصنف محسن ذو أداء أفضل عن العشيرة الأصلية. وأيضا أظهرت النتائج بصفة عامة، أن دورتي الإنتخاب للسلالة الخضرية من العشائر بينت كفاءة عالية في تحسين كل الصفات المدروسة

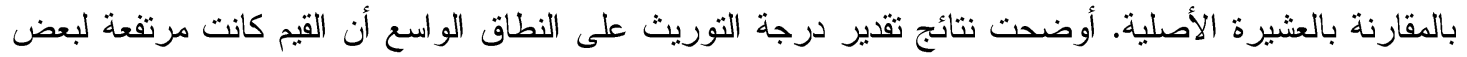
الصفات و أعلاهم صفة المادة الجافة وكانت القيم منخفضة لبعض الصفات وأكثرهم صفة قطر الجذر . وكانت قيم

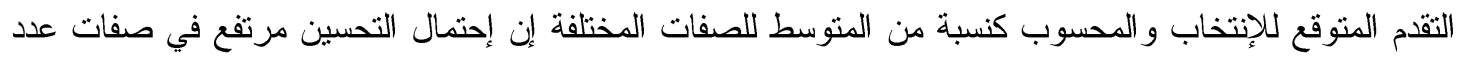

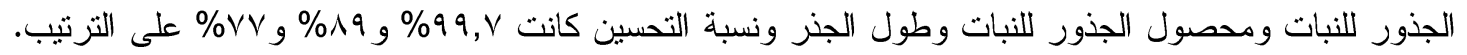

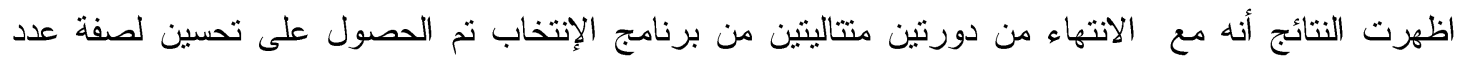

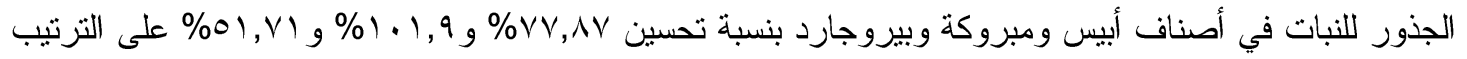
بالنسبة للعثيرة الاصلية. أظهرت النتائج أن صنف أبيس أعطى أعلى القيم المعنوية عند مقارنته بباقي الأصناف الأخرى لصفات المادة الجافة والــ TSS ونسبة الكاروتين. وأن الصنف أبيس اظهر أعلى القيم لصفة محصول

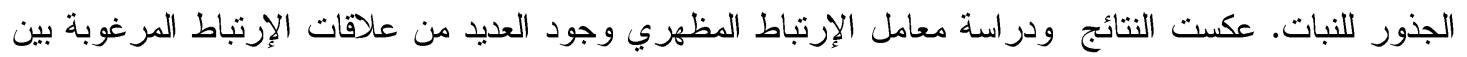
أزواج الصفات المختلفة، مما يعكس اهمية أخذها في الإعتبار عند إجراء الانتخاب كأحد الوسائل الهامة التي يمكن أن يستفيد بها مربي النباتات في بر امج الإنتخاب. 